\title{
Antibacterial, anti-inflammatory and antioxidant activities of Mahanintangtong and its constituent herbs, a formula used in Thai traditional medicine for treating pharyngitis
}

Bhanuz Dechayont ${ }^{1 *}$ (D), Pathompong Phuaklee', Jitpisute Chunthorng-Orn', Thana Juckmeta', Onmanee Prajuabjinda ${ }^{1}$ and Kitrawee Jiraratsatit ${ }^{2}$

\begin{abstract}
Background: Mahanintangtong is listed in the Thailand's National List of Essential Medicines (NLEM). It is used to treat non-specific fevers and illnesses such as pharyngitis and chickenpox. In this study, we investigated the biological activities of the different medicinal plants used in the Mahanintangtong formula.

Methods: The plant materials were extracted by maceration and decoction. Antimicrobial activity, assessed by disc diffusion method, the minimum inhibitory concentration (MIC), and minimum bactericidal concentration (MBC) were compared with commercially available standard antibiotics. To elucidate the anti-inflammatory mechanisms, inhibition of nitric oxide (NO), tumor necrosis factor a (TNF-a), and interleukin 6 (IL-6) production was tested by Griess and ELISA techniques. Antioxidant activity was measured by ABTS and DPPH scavenging assays.

Results: The extracts with the best antimicrobial activities were carbonized Tectona grandis showing against Streptococcus pyogenes, Staphylococcus aureus, Methicillin-resistant Staphylococcus aureus (MRSA) and Pseudomonas aeruginosa. The ethanol extract of Dracaena loureiroi wood exhibited the highest NO and IL-6 inhibitory activity with $I_{50}$ values of $9.42 \pm 1.81$ and $12.02 \pm 0.30 \mu \mathrm{g} / \mathrm{mL}$, respectively. The ethanol extract of Pogostemon cablin had the highest TNF-a inhibitory with $I C_{50}$ values of $10.68 \pm 0.02 \mu \mathrm{g} / \mathrm{mL}$. In anti-free radical testing, the ethanol extract of D. loureiroi displayed high antioxidant activity by both ABTS and DPPH assays.
\end{abstract}

Conclusion: The ethanol extracts from carbonized T. grandis and Mahanintangtong showed good antimicrobial activity, especially against S. pyogenes, and good anti-inflammatory activity. These findings are relevant to the pathogenesis of pharyngitis and justify additional studies to see if Mahanintangtong could have clinical utility.

Keywords: Streptococcus pyogenes, Nitric oxide (NO), Tumor necrosis factor a (TNF-a), Interleukin 6 (IL-6), Thailand National List of essential medicines, Pharyngitis

\footnotetext{
* Correspondence: Nuzz@hotmail.com

'Department of Applied Thai Traditional Medicine, Faculty of Medicine,

Thammasat University, Pathum Thani 12120, Thailand

Full list of author information is available at the end of the article
}

(c) The Author(s). 2021 Open Access This article is licensed under a Creative Commons Attribution 4.0 International License, which permits use, sharing, adaptation, distribution and reproduction in any medium or format, as long as you give appropriate credit to the original author(s) and the source, provide a link to the Creative Commons licence, and indicate if changes were made. The images or other third party material in this article are included in the article's Creative Commons licence, unless indicated otherwise in a credit line to the material. If material is not included in the article's Creative Commons licence and your intended use is not permitted by statutory regulation or exceeds the permitted use, you will need to obtain permission directly from the copyright holder. To view a copy of this licence, visit http://creativecommons.org/licenses/by/4.0/ The Creative Commons Public Domain Dedication waiver (http://creativecommons.org/publicdomain/zero/1.0/) applies to the data made available in this article, unless otherwise stated in a credit line to the data. 


\section{Background}

Pharyngitis is inflammation of the pharynx that is most often caused by viruses but may also be caused by bacteria, notably, Streptococcus pyogenes (group A Streptococcus [GAS]) [1]. One of the first defenses against infection is a host-mounted inflammatory response involving a variety of cytokines and chemokines which both trigger and/or enhance the specific inflammatory response [2].

Inflammation is a complex process that is coordinated by cytokines and immune signalling molecules [3]. The concept of the immune signalling which induces fever during infection and inflammation has been widely accepted. The well-identified pathways of inflammation are either activated by lipopolysaccharide (LPS) or by key cytokines such as IL-6, IL- $1 \beta$, TNF- $\alpha$ and others. Other putative endogenous mediators like lipocortin-1 are also involved in fever $[4,5]$.

LPS and proinflammatory cytokines can catalyse the formation of small signalling molecules such as nitric oxide (NO), which plays a key role in the pathogenesis of inflammation. NO has an anti-inflammatory effect under normal physiological conditions but it is a proinflammatory mediator that induces inflammation due to its over production in acute inflammatory states and physiological stress [6]. Therefore, finding the inhibitors which are able to block inflammatory cytokines are important for reducing the inflammatory response.

For treating common bacterial infections like a streptococcal sore throat, penicillin is commonly recommended to decrease symptoms and to prevent subsequent complications and the spread of infection $[7,8]$. However, drug side effects and microbial resistance are two reasons for the renewed interest in traditional herbal medicines. The use of plant-based formulations is potentially a viable option for reducing the side effects associated with conventional antibiotic treatment $[9,10]$ as well as increase the number of compounds that could be used for treating infections or acting synergistically with current therapies [11].

Thailand's National List of Essential Medicines (NLEM), a knowledge repository of Thai traditional herbal medicine, includes information on single herbs and herbal combinations used for treating pharyngitis. The herbal combinations are typically composed of herbs with complimentary properties. Mahanintangtong is a herbal combination described in NLEM for treating non-specific fevers as well as pharyngitis and chickenpox. The formula consists of several herbal plants: carbonized seeds of Entada rheedii Spreng, carbonized seeds of Spondias pinnata (L.f.) Kurz, carbonized pulp of Sapindus rarak DC, carbonized wood of Calamus caesius Blume, carbonized wood of Tectona grandis L.f., Dracaena loureiroi Gagnep, Myristica fragrans Houtt, and the leaves of Pogostemon cablin (Blanco) Benth, Tiliacora triandra (Colebr.), Diels, Chinese ink (Inkstick), and Shell of Monetaria moneta (Money cowry) [12].

Previous phytochemical and pharmacological studies have shown that plant extracts have anti-inflammatory properties but no specific work has been done on the Mahanintangtong formula. Therefore, we tested extracts from Mahanintangtong for antibacterial, anti-inflammatory and antioxidant properties.

\section{Methods \\ Chemicals and reagents}

All the chemicals and reagents used were of analytical grade. 2, 2-Diphenyl-1-picrylhydrazyl (DPPH), and butylated hydroxytoluene (BHT) were purchased from Fluka, Germany. Acetic acid was purchased from Merck, Germany. 2,2' -Azino-bis (3-ethylbenzo-thiazoline-6-sulfonic acid) diammonium salt, 6-hydroxy-2,5,7,8-tetramethylchroman-2-carboxylic acid, potassium persulfate, dimethyl sulfoxide, lipopolysaccharide from E.coli O55: B5 (LPS), phosphoric acid, N-(1-Naphthyl) ethylenediamine dihydrochloride, sulfanilamide,3-(4,5-Dimethyl-2thiazolyl)-2,5-dipheyl-2H-tetrazolium bromide or thiazolyl blue tetrazolium bromide (MTT) were purchased from Sigma-Aldrich, USA. Dulbecco's modified eagle medium (DMEM), Foetal bovine serum (FBS), Trypan blue stain $0.4 \%$ and Trypsin-EDTA were obtained from Gibco, USA. Hydrochloric acid and isopropanol were obtained from RCI Labscan, Thailand; Phosphatebuffered saline (PBS) was provided by Biochrom, Germany and mouse TNF- $\alpha$ and IL-6 ELISA kits were purchased from ImmunoTools, Germany.

\section{Plant material and preparation of extracts}

The plant materials were purchased from a licensed traditional medicine drug store, Charoensuk Osod in Nakorn Pathom, Thailand. The herbal materials were identified and authenticated by Department of Applied Thai Traditional Medicine, Thammasat University. A voucher specimen is kept at the Herbarium of the Faculty of Pharmaceutical Sciences, Prince of Songkla University, Thailand. A voucher specimen is shown in Table 1. Then the plant materials were crushed in to small pieces for the extraction process. The formula was prepared from 11 ingredients; its constituents are shown in Table 1.

Seeds of Entada rheedii and Spondias pinnata, pulp of Sapindus rarak, wood of Calamus caesius and Tectona grandis were carbonized following the Thai Traditional method: heated at $300^{\circ} \mathrm{C}$ in clay pot for $24 \mathrm{~h}$., and, then, as charcoal, for a further $6 \mathrm{~h}$, before cooling at room temperature. 
Table 1 Yields (\%w/w), plant name, part of plant used, voucher specimen and \% in formulation of different components of the Mahanintangtong formula and its constituent herbs

\begin{tabular}{|c|c|c|c|c|c|c|}
\hline Plant name & Family & Part used & Voucher specimen & Formulation (\%wt) & Extracts type & $\%$ Yield \\
\hline \multirow[t]{2}{*}{ Entada rheedii Spreng. (carbonized) } & Fabaceae & Seed & SKP 098/115 051801 & 9.71 & Ethanol & 3.96 \\
\hline & & & & & Water & 9.46 \\
\hline \multirow[t]{2}{*}{ Spondias pinnata (L.f.) Kurz. (carbonized) } & Anacardiaceae & Seed & SKP 009191601 & 9.71 & Ethanol & 6.20 \\
\hline & & & & & Water & 1.95 \\
\hline \multirow[t]{2}{*}{ Sapindus rarak DC. (carbonized) } & Sapindaceae & Pulp & SKP 170190501 & 9.71 & Ethanol & 4.64 \\
\hline & & & & & Water & 2.98 \\
\hline \multirow[t]{2}{*}{ Calamus caesius Blume. (carbonized) } & Arecaceae & Wood & SKP 137030301 & 9.71 & Ethanol & 0.58 \\
\hline & & & & & Water & 4.20 \\
\hline \multirow[t]{2}{*}{ Tectona grandis L.f. (carbonized) } & Lamiaceae & Wood & SKP 095200701 & 9.71 & Ethanol & 0.84 \\
\hline & & & & & Water & 0.32 \\
\hline \multirow[t]{2}{*}{ Dracaena loureiroi Gagnep. } & Asparagaceae & Wood & SKP 065041201 & 9.71 & Ethanol & 17.79 \\
\hline & & & & & Water & 1.48 \\
\hline \multirow[t]{2}{*}{ Myristica fragrans Houtt. } & Myristicaceae & Wood & SKP 121130601 & 9.71 & Ethanol & 3.94 \\
\hline & & & & & Water & 2.00 \\
\hline \multirow[t]{2}{*}{ Pogostemon cablin (Blanco) Benth. } & Lamiaceae & Leaves & SKP 095160301 & 9.71 & Ethanol & 7.47 \\
\hline & & & & & Water & 12.70 \\
\hline \multirow[t]{2}{*}{ Tiliacora triandra Diels } & Menispermaceae & Leaves & SKP 114202001 & 9.71 & Ethanol & 3.94 \\
\hline & & & & & Water & 6.54 \\
\hline \multirow[t]{2}{*}{ Chinese ink } & - & - & - & 9.71 & Ethanol & N/A \\
\hline & & & & & Water & 2.92 \\
\hline \multirow{2}{*}{$\begin{array}{l}\text { Monetaria moneta } \\
\text { (Money cowry) }\end{array}$} & Cypraeidae & Shell & - & 2.90 & Ethanol & N/A \\
\hline & & & & & Water & 0.40 \\
\hline \multirow[t]{2}{*}{ Mahanintangtong formula } & - & - & - & - & Ethanol & 4.98 \\
\hline & & & & & Water & 4.12 \\
\hline
\end{tabular}

N/A Not Applicable

\section{Extraction method}

\section{Maceration method}

This followed the method of Dechayont et al. [13]. The Mahanintangtong formula and its individual herb components were dried in an oven at $50{ }^{\circ} \mathrm{C}$. The dried materials $(50 \mathrm{~g})$ were then extracted three times with $95 \%$ ethanol $(\mathrm{EtOH})$ at room temperature $(72 \mathrm{~h})$ and filtered through Whatman No. 1 filter paper. The extracts were evaporated in a rotary evaporator and vacuum to dryness to give the crude ethanol extract.

\section{Decoction method}

Decoction was performed according to the method of Thai traditional medicine. The Mahanintangtong formula and the individual herbs $(30 \mathrm{~g})$ were boiled in distilled water for $15 \mathrm{~min}$, cooled and then reboiled twice more. The aqueous mix was filtered through Whatman No. 1 filter paper and dried using a lyophilizer to give the crude water extract.
The ethanol and water extract yields were calculated as $\mathrm{w} / \mathrm{w}$ and expressed as percentages (Table 1 ) and were stored at $-20^{\circ} \mathrm{C}$.

\section{Antimicrobial assay \\ Microbial strains}

Cultures of the following microorganisms were used in the study: Staphylococcus aureus ATCC 25923; methicillin resistant Staphylococcus aureus (MRSA) ATCC 20651, Streptococcus pyogenes ATCC 19615, Pseudomonas aeruginosa ATCC 9097 and Candida albicans ATCC 90028.

\section{Disc diffusion method}

The agar disc diffusion method was used to determine the antimicrobial activities of the extract, as described previously $[14,15]$. Paper discs $(6 \mathrm{~mm}$ diameter) were added to the extracts (conc. $5 \mathrm{mg} /$ disc for ethanol extract, and conc. $1 \mathrm{mg} /$ disc for water extract). The inoculum density was adjusted to 0.5 of the McFarland 
standard. Air-dried discs were placed on inoculated Mueller-Hinton agar (MHA) for S. aureus, MRSA and $P$. aeruginosa, MHA with $5 \%$ sheep blood for $S$. pyogenes and Sabouraud Dextrose agar (SDA) for C. albicans. Positive controls were amoxicillin, ampicillin, gentamicin and vancomycin, each at a concentration of $10 \mu \mathrm{g} /$ disc. These plates were incubated at $37^{\circ} \mathrm{C}$ for $24 \mathrm{~h}$ for bacteria and at $37^{\circ} \mathrm{C}$ for $48 \mathrm{~h}$ for C. albicans. The zone of inhibition was calculated by measuring the diameter of the inhibition zone. The readings were taken in three different fixed directions in all 3 replicates and the mean value was tabulated.

\section{Determination of the minimal inhibitory concentration (MIC)}

The minimal inhibitory concentration (MIC) of an antimicrobial agent is the lowest concentration of the antimicrobial agent that inhibits a given bacterial isolate from multiplying and producing visible growth in the test system [16]. Isolated colonies were prepared from 18 to $24 \mathrm{~h}$ cultures of S. aureus, MRSA, S. pyogenes and from 36 to $48 \mathrm{~h}$ cultures of C. albicans on an agar plate. Then the inoculum was adjusted with Mueller-Hinton broth (MHB) medium to $0.5 \mathrm{McF}$ arland standard using a densitometer and the cultures were diluted 200 - fold. In sterile 96 - well microtiter plates, $50 \mu \mathrm{L}$ of a plant extract was diluted 2 -fold with broth (10 concentrations). Triplicate samples were used for each test concentration. After incubation for $16-18 \mathrm{~h}$ of S. aureus, MRSA, S. pyogenes and for $36-48 \mathrm{~h}$ cultures of C. albicans at $37^{\circ} \mathrm{C}$, $10 \mu \mathrm{L}$ of resazurin solution was added in each well and incubated for $2 \mathrm{~h}$. The lowest concentration value was determined in triplicate.

\section{Determination of the minimum bactericidal concentration (MBC)}

Innocula from the wells that had no visible growth were transferred to the agar plates in quadrants and were incubated at $37^{\circ} \mathrm{C}$ for $24 \mathrm{~h}$ and then examined for bacterial growth. The last quadrant (i.e. with the lowest concentration of plant extract) that showed no growth was taken as the MBC. Values were recorded as $\mathrm{mg} / \mathrm{ml}$ and all experiments were performed in triplicate [17].

\section{In vitro assay for anti-inflammatory assay}

\section{Cell line}

The inhibitory effects of nitric oxide (NO), TNF- $\alpha$ and IL-6 production were evaluated using murine macrophage like RAW 264.7 cells. The RAW 264.7 cell line was cultured in DMEM medium supplemented with $10 \%$ heated fetal bovine serum and $50 \mathrm{IU} / \mathrm{mL}$ penicillin and $50 \mu \mathrm{g} / \mathrm{mL}$ streptomycin. The cells were detached with trypsin-EDTA and diluted to a suspension in fresh medium.

\section{Assay for NO inhibitory effect}

The evaluation of the NO inhibitory activity was performed in a manner similar to that described for cell viability [18]. The cells were seeded at a density of $1 \times 10^{5}$ cells/well in 96-well microplates and incubated to adhere for $24 \mathrm{~h}$ at $37^{\circ} \mathrm{C}$ in a humidified atmosphere containing $5 \% \mathrm{CO}_{2}$. After that the medium was replaced with fresh medium containing a final concentration at $5 \mathrm{ng} / \mathrm{mL}$ of LPS. The adherent cells were treated with test samples at six concentrations to give a total volume of $200 \mu \mathrm{L} /$ well and incubated for $24 \mathrm{~h}$. Twenty-four hours later, the presence of nitrite was determined in cell culture media using Griess reagent at $570 \mathrm{~nm}$. Inhibition (\%) was calculated using the following equation and the $\mathrm{IC}_{50}$ value was calculated graphically using GraphPad 4.0 software in triplicate (Prism, USA).

The\% of inhibition $=($ Abs.Control - Abs.Sample $) /$ Abs.Control $\times 100$

\section{TNF- $\alpha$ and IL- 6 inhibitory effect in RAW264.7 cells by ELISA}

RAW 264.7 cells were incubated for $24 \mathrm{~h}$ with $5 \mathrm{ng} / \mathrm{mL}$ of LPS and various concentrations of extracts. After 24 $h$, supernatants were tested for the production of TNF- $\alpha$ and IL-6 quantified using an ELISA kit (ImmunoTools), following the manufacturer's instructions; the optical density (OD) at $450 \mathrm{~nm}$ was determined on a plate reader [19]. The experiment compared potential with andrographolide as positive control which is a major active compound from the Andrographis paniculata plant.

\section{Assay for cytotoxicity - MTT assay}

The cell viability of test sample was performed using the 3-(4,5-dimethyl-2-thiazolyl)-2,5-diphenyl-2H-tetrazolium bromide (MTT) colorimetric method. The RAW 264.7 macrophages were cultured in 96-well plates and allowed to grow at $37^{\circ} \mathrm{C}$ in $5 \% \mathrm{CO}_{2}$ for $24 \mathrm{~h}$. Subsequently, the cells were tested with samples at six concentrations and, after $48 \mathrm{~h}$, MTT solution $(5 \mathrm{mg} / \mathrm{mL}$ of MTT in PBS) was added to the wells. Following $4 \mathrm{~h}$ of incubation, the medium was removed and $100 \mu \mathrm{L}$ of isopropanol containing $0.04 \mathrm{M} \mathrm{HCl}$ was added to dissolve the formazan production in the cells. The OD of formazan solution was measured with a microplate reader at $570 \mathrm{~nm}$ [20]. The test simples were considered to be cytotoxic when the OD of the sample-treated group was less than $70 \%$ of that in the control (vehicle-treated) group. All determinations were carried out in triplicate. 
The percentage survival of the cell growth at each extract is calculated as:

$$
\begin{aligned}
\text { The } \% \text { of Survival }= & (\text { Abs.Sample/Abs.Control }) \\
& \times 100
\end{aligned}
$$

\section{Antioxidant activity}

\section{$D P P H$ radical scavenging assay}

A stock solution of DPPH solution in absolute $\mathrm{EtOH}$ $\left(6 \times 10^{-5} \mathrm{M}\right)$ was freshly prepared and protected from light [17]. The herb extracts were prepared in a serial dilution (5 concentrations). The extracts $100 \mu \mathrm{L}$ were individually added and mixed with an equal volume of DPPH solution in 96-well microplates and maintained in the dark at room temperature for $30 \mathrm{~min}$. The absorbance was measured at $520 \mathrm{~nm}$. The scavenging activity was calculated as a percentage inhibition in the formula (3) below:

The\% of inhibition $=($ Abs.Control-Abs.Sample $) /$ Abs.Control $\times 100$

The $\mathrm{IC}_{50}$ was calculated from a dose-response curve using GraphPad 4.03 software.

\section{$A B T S$ radical cation decolorization assay}

The ABTS reagent was prepared by mixing ABTS $7 \mathrm{mM}$ concentration with $2.45 \mathrm{mM}$ potassium persulfate in deionized water and left in the dark at room temperature for $12-16 \mathrm{~h} \mathrm{[21]}$. The mixture reagent was diluted with deionized water to give an absorbance of $0.700 \pm 0.020$ at $734 \mathrm{~nm}$. Serial dilutions of the herbal extracts were made in absolute EtOH for the ethanol extracts and distilled water for the aqueous extracts. ABTS reagent $(180 \mu \mathrm{L})$ was mixed with $20 \mu \mathrm{L}$ of sample solution at five concentrations and the absorbance was measured after exactly $6 \mathrm{~min}$ at $734 \mathrm{~nm}$ in 96 -well microplates to determine the scavenging activity. All determinations were carried out in triplicate. The scavenging activity was calculated as a percentage inhibition in the formula (4) below.

$$
\begin{aligned}
& \text { The Percentage of inhibition } \\
& =(\text { Abs.Control - Abs.Sample)/Abs.Control } \\
& \quad \times 100
\end{aligned}
$$

The $\mathrm{IC}_{50}$ was calculated from a dose-response curve using GraphPad 4.03 software.

\section{Statistical analysis}

All the experiments were conducted in triplicate. Results are expressed as mean \pm standard error of the mean.

\section{Results}

Preparation of extracts

The yield percentages of Mahanintangtong formula and its 11 components are shown in Table 1. The maximal extract yield by maceration was the wood of $D$. loureiroi $(17.79 \%)$ whilst the highest yield by decoction was the leaves of P. cablin (12.70\%).

\section{Antimicrobial assay}

The antimicrobial activities of ethanol and water extracts were tested on all the ATCC bacteria and C. albicans using the disc diffusion assay, which was assessed by the presence and absence of inhibition zones. The ethanol and water extracts were tested at 5 and $1 \mathrm{mg} /$ disc, respectively. In the control tests, DMSO was shown to have no inhibitory effect on any of the bacteria tested. The positive controls were amoxicillin, vancomycin, ampicillin and gentamicin. Based on inhibition zone test results, the ethanol extract of $T$. grandis (carbonized), $S$. pinnata (carbonized), and Mahanintangtong formula produced moderate activity against $S$. pyogenes, $S$. aureus and MRSA (inhibition zone $>10 \mathrm{~mm}$, Table 2) while all the extracts showed no significant inhibition zones against $C$. albicans.

The MIC and MBC were measured to assess the potency of Mahanintangtong formula and its component extracts using the microdilution assay. These methods confirmed the results obtained by the disc diffusion method. The ethanol extracts were the most active: $E$. rheedii (carbonized), S. pinnata (carbonized), S. rarak (carbonized) and P. cablin extracts inhibited S. pyogenes with a MIC and MBC of $0.039 \mathrm{mg} / \mathrm{mL}$. All the ethanol and water extracts except Chinese ink and money cowry showed activity against $S$. aureus with MICs and MBCs of $0.625-2.5 \mathrm{mg} / \mathrm{mL}$, respectively. Although the ethanol extract of $C$. caesius was potent against $S$. aureus, it did not inhibit MRSA. The highest MIC against MRSA was $0.3125 \mathrm{mg} / \mathrm{mL}$ from ethanol extract of $D$. loureiri. The ethanol extract of E. rheedii (carbonized), T. grandis (carbonized), P. cablin and Mahanintangtong formula (herbal mix) showed the highest MIC and MBC values of $0.625 \mathrm{mg} / \mathrm{mL}$ against $P$. aeruginosa. None of the ethanol extracts had inhibitory activity against $C$. albicans.

\section{Anti-inflammatory assay}

The ethanol extract of $D$. loureiroi exhibited highest NO inhibitory activity with $\mathrm{IC}_{50}$ values of $9.42 \pm 1.81 \mu \mathrm{g} / \mathrm{mL}$. The $\mathrm{IC}_{50}$ for Mahanintangtong formula was higher at $28.03 \pm 0.64 \mu \mathrm{g} / \mathrm{mL}$.

The ethanol extract of $P$. cablin had the highest inhibitory activity against TNF- $\alpha$ production with an $\mathrm{IC}_{50}=$ $10.61 \pm 0.04 \mu \mathrm{g} / \mathrm{mL}$; values for the wood of $M$. fragrans and carbonized wood of $T$. grandis were $14.03 \pm 2.12 \mu \mathrm{g} /$ $\mathrm{mL}$ and $21.26 \pm 0.40 \mu \mathrm{g} / \mathrm{mL}$, respectively. IL-6 inhibition 
Table 2 Antimicrobial activity against five microorganisms of Mahanintangtong formula and its constituent herbs $(n=3)$

\begin{tabular}{|c|c|c|c|c|c|c|}
\hline \multirow[t]{2}{*}{ Plant name } & \multirow{2}{*}{$\begin{array}{l}\text { Extracts } \\
\text { type }\end{array}$} & \multicolumn{5}{|c|}{ Diameter of inhibition zone $(\mathrm{mm} .)^{*}, \mathrm{MIC}(\mu \mathrm{g} / \mathrm{mL})^{* *}, \mathrm{MBC}(\mu \mathrm{g} / \mathrm{mL})^{* * *}$} \\
\hline & & S. pyogenes & S. aureus & MRSA & P. aeruginosa & C. albicans \\
\hline \multirow[t]{2}{*}{ Entada rheedii (carbonized) } & Ethanol & $\begin{array}{l}11.00 \pm 0.00^{*} \\
0.039^{* *} \\
0.039^{* *^{\prime *}}\end{array}$ & $\begin{array}{l}11.33 \pm 0.58^{*} \\
0.625^{* *} \\
0.625^{* * * *}\end{array}$ & $\begin{array}{l}11.21 \pm 1.73^{*}, \\
5^{* * 2} \\
5^{* * *}\end{array}$ & $\begin{array}{l}0^{*} \\
0.625^{* *} \\
0.625^{* *^{\prime}}\end{array}$ & $\begin{array}{l}0^{*}, \\
>5^{* *} \\
>5^{* *^{\prime}}\end{array}$ \\
\hline & Water & $\begin{array}{l}0^{*} \\
>5^{* *^{*}} \\
>5^{* *^{\prime}}\end{array}$ & $\begin{array}{l}0^{*} \\
0.625^{* *} \\
0.625^{* *^{\prime}}\end{array}$ & $\begin{array}{l}0^{*} \\
1.25^{* *} \\
1.25^{* * *}\end{array}$ & $\begin{array}{l}0^{*} \\
0.625^{* *} \\
2.5^{* * *}\end{array}$ & $\begin{array}{l}0^{*}, \\
>5^{* *} \\
>5^{* *^{\prime}}\end{array}$ \\
\hline \multirow[t]{2}{*}{ Spondias pinnata (carbonized) } & Ethanol & $\begin{array}{l}12.67 \pm 2.52 \\
0.039 \\
0.039^{* * *}\end{array}$ & $\begin{array}{l}11.33 \pm 0.58 \\
0.625_{1 *} \\
0.625^{* * *}\end{array}$ & $\begin{array}{l}12.00 \pm 0.00 \\
0.625 \\
0.625^{* * *}\end{array}$ & $\begin{array}{l}8.33 \pm 0.58 \\
>5 \\
>5^{* * *}\end{array}$ & $\begin{array}{l}0 \\
>5 \\
>5^{* * *}\end{array}$ \\
\hline & Water & $\begin{array}{l}0^{*}, \\
>5^{* *^{*}} \\
>5^{* *^{\prime}}\end{array}$ & $\begin{array}{l}0^{*}, \\
0.625^{* *} \\
0.625^{* *^{\prime}}\end{array}$ & $\begin{array}{l}0^{*} \\
0.625^{* *} \\
0.625^{* * *}\end{array}$ & $\begin{array}{l}0^{*} \\
5^{* *} \\
>5^{* * * *}\end{array}$ & $\begin{array}{l}0^{*}, \\
>5^{* *} \\
>5^{* *^{\prime}}\end{array}$ \\
\hline \multirow[t]{2}{*}{ Sapindus rarak (carbonized) } & Ethanol & $\begin{array}{l}10.33 \pm 1.52^{*}, \\
0.039^{* *} \\
0.039^{* *^{*}}\end{array}$ & $\begin{array}{l}0^{*}, \\
0.625^{* *} \\
0.625^{* *^{\prime}}\end{array}$ & $\begin{array}{l}0^{*} \\
0.625^{* *} \\
0.625^{* * *}\end{array}$ & $\begin{array}{l}0^{*} \\
0.625^{* *} \\
0.625^{* * *}\end{array}$ & $\begin{array}{l}0^{*}, \\
>5^{* *} \\
>5^{* *^{\prime}}\end{array}$ \\
\hline & Water & $\begin{array}{l}0^{*}, \\
>5^{* *} \\
>5^{* *^{\prime}}\end{array}$ & $\begin{array}{l}0^{*}, \\
1.25^{* *} \\
1.25^{* *^{\prime *}}\end{array}$ & $\begin{array}{l}0^{*} \\
1.25^{* *} \\
2.5^{* * *}\end{array}$ & $\begin{array}{l}0^{*} \\
>5^{* *} \\
>5^{* * *}\end{array}$ & $\begin{array}{l}0^{*}, \\
>5^{* *} \\
>5^{* *^{\prime}}\end{array}$ \\
\hline \multirow[t]{2}{*}{ Calamus caesius (carbonized) } & Ethanol & $\begin{array}{l}0^{*} \\
0.3125^{* *} \\
0.625^{* * *^{\prime}}\end{array}$ & $\begin{array}{l}0^{*} \\
2.5^{* *} \\
2.5^{* * *}\end{array}$ & $\begin{array}{l}0^{*} \\
>5^{* *} \\
>5^{* *^{\prime *}}\end{array}$ & $\begin{array}{l}0^{*}, \\
0.625^{* *} \\
2.5^{* * *}\end{array}$ & $\begin{array}{l}0^{*}, \\
>5^{* *} \\
>5^{* *^{\prime}}\end{array}$ \\
\hline & Water & $\begin{array}{l}0^{*} \\
>5^{* *} \\
>5^{* *^{\prime *}}\end{array}$ & $\begin{array}{l}0^{*} \\
2.5^{* *} \\
2.5^{* * *}\end{array}$ & $\begin{array}{l}0^{*} \\
5^{* *} \\
>5^{* * * *}\end{array}$ & $\begin{array}{l}0^{*} \\
5^{* *} \\
>5^{* * * *}\end{array}$ & $\begin{array}{l}0^{*} \\
>5^{* * *} \\
>5^{* * *^{\prime}}\end{array}$ \\
\hline \multirow[t]{2}{*}{ Tectona grandis (carbonized) } & Ethanol & $\begin{array}{l}13.33 \pm 0.58^{*} \\
0.078^{* * *} \\
0.078^{* *^{*}}\end{array}$ & $\begin{array}{l}13.00+0.00^{*}, \\
0.625^{* * *}, \\
1.25^{* * *}{ }^{\prime}\end{array}$ & $\begin{array}{l}14.33 \pm 0.58^{*} \\
0.625^{* *} \\
0.625^{* * *}\end{array}$ & $\begin{array}{l}0^{*} \\
0.625^{* *} \\
0.625^{* * *}\end{array}$ & $\begin{array}{l}0^{*}, \\
>5^{* *} \\
5^{* * *}\end{array}$ \\
\hline & Water & $\begin{array}{l}0^{*}, \\
>5^{* *} \\
>5^{* *^{\prime}}\end{array}$ & $\begin{array}{l}8.00 \pm 0.00^{*} \\
0.625^{* *} \\
0.625^{* * * *}\end{array}$ & $\begin{array}{l}10.33 \pm 1.53^{*} \\
2.5^{* *} \\
2.5^{* * *}\end{array}$ & $\begin{array}{l}0^{*} \\
2.5^{* *} \\
2.5^{* * * *}\end{array}$ & $\begin{array}{l}0^{*} \\
>5^{* *} \\
>5^{* *^{\prime}}\end{array}$ \\
\hline \multirow[t]{2}{*}{ Dracaena loureiroi } & Ethanol & $\begin{array}{l}12.33 \pm 0.58^{*} \\
0.156^{* *} \\
0.156^{* *^{\prime *}}\end{array}$ & $\begin{array}{l}11.00 \pm 0.00^{*}, \\
0.625^{* *}, \\
0.625^{* * * *}\end{array}$ & $\begin{array}{l}10.33 \pm 0.58^{*}, 0.3125^{* *} \\
0.625^{* * * *}\end{array}$ & $\begin{array}{l}0^{*} \\
1.25^{* *} \\
>5^{* * *}\end{array}$ & $\begin{array}{l}0^{*} \\
>5^{* *} \\
>5^{* * *}\end{array}$ \\
\hline & Water & $\begin{array}{l}0^{*} \\
>5^{* *} \\
>5^{* * *}\end{array}$ & $\begin{array}{l}0^{*}, \\
0.625^{* *} \\
0.625^{* *^{\prime *}}\end{array}$ & $\begin{array}{l}0^{*} \\
0.625^{* *} \\
0.625^{* * *}\end{array}$ & $\begin{array}{l}0^{*} \\
5^{* *} \\
>5^{* * * *}\end{array}$ & $\begin{array}{l}0^{*}, \\
>5^{* *} \\
>5^{* * *}\end{array}$ \\
\hline \multirow[t]{2}{*}{ Myristica fragrans } & Ethanol & $\begin{array}{l}10.33 \pm 1.15^{*} \\
0.625^{* *} \\
0.156^{* *^{*}}\end{array}$ & $\begin{array}{l}0^{*}, \\
0.625^{* *} \\
0.625^{* *^{\prime}}\end{array}$ & $\begin{array}{l}0^{*} \\
0.625^{* *} \\
0.625^{* * *}\end{array}$ & $\begin{array}{l}0^{*} \\
0.625^{* *} \\
>5^{* * *}\end{array}$ & $\begin{array}{l}0^{*}{ }_{1}^{*{ }^{*}} \\
>5^{*{ }^{\prime}} \\
>5^{* *^{\prime}}\end{array}$ \\
\hline & Water & $\begin{array}{l}0^{*}, \\
>5^{* *} \\
>5^{* *^{\prime *}}\end{array}$ & $\begin{array}{l}0^{*} \\
0.625^{* *} \\
0.625^{* *^{\prime}}\end{array}$ & $\begin{array}{l}0^{*} \\
0.625^{* *} \\
0.625^{* * * *}\end{array}$ & $\begin{array}{l}0^{*} \\
1.25^{* *} \\
>5^{* * *}\end{array}$ & $\begin{array}{l}0^{*}, \\
>5^{* *} \\
>5^{* *^{*}}\end{array}$ \\
\hline \multirow[t]{2}{*}{ Pogostemon cablin } & Ethanol & $\begin{array}{l}10.33 \pm 1.15^{*} \\
0.039^{* * *} \\
0.039^{* *^{*}}\end{array}$ & $\begin{array}{l}10.33 \pm 2.52^{*} \\
0.625^{* *} \\
0.625^{* * * *}\end{array}$ & $\begin{array}{l}11.67 \pm 1.53^{*} \\
5^{* *} \\
5^{* * *}\end{array}$ & $\begin{array}{l}0^{*} \\
0.625^{* *} \\
0.625^{* *^{\prime}}\end{array}$ & $\begin{array}{l}0^{*}, \\
>5^{* *} \\
>5^{* *^{\prime}}\end{array}$ \\
\hline & Water & $\begin{array}{l}0^{*}, \\
>5^{* *} \\
>5^{* *^{\prime *}}\end{array}$ & $\begin{array}{l}0^{*} \\
0.625^{* *} \\
0.625^{* *^{\prime}}\end{array}$ & $\begin{array}{l}8.33 \pm 1.53^{*} \\
2.5^{* *} \\
2.5^{* * *}\end{array}$ & $\begin{array}{l}0^{*} \\
1.25^{* *} \\
1.25^{* * *}\end{array}$ & $\begin{array}{l}0^{*}, \\
>5^{* *} \\
>5^{* * *^{\prime}}\end{array}$ \\
\hline \multirow[t]{2}{*}{ Tiliacora triandra } & Ethanol & $\begin{array}{l}8.33 \pm 0.58^{*} \\
0.078^{* *} \\
0.078^{* *^{\prime *}}\end{array}$ & $\begin{array}{l}0^{*}, \\
0.625^{* *} \\
0.625^{* *^{*}}\end{array}$ & $\begin{array}{l}8 \pm 0.00^{*} \\
5^{* *} \\
5^{* * *}\end{array}$ & $\begin{array}{l}7 \pm 0.00^{*} \\
5^{* *} \\
>5^{* * *}\end{array}$ & $\begin{array}{l}0^{*}, \\
>5^{* *^{*}} \\
>5^{* *^{\prime}}\end{array}$ \\
\hline & Water & $\begin{array}{l}0^{*}, \\
>5^{* *} \\
>5^{* * *}\end{array}$ & $\begin{array}{l}0^{*} \\
0.625^{* *} \\
0.625^{* * *}\end{array}$ & $\begin{array}{l}0^{*}, \\
1.25^{* *} \\
2.5^{* * *}\end{array}$ & $\begin{array}{l}0^{*} \\
>5^{* *} \\
>5^{* * * *}\end{array}$ & $\begin{array}{l}0^{*}, \\
>5^{* *} \\
>5^{* * *}\end{array}$ \\
\hline
\end{tabular}


Table 2 Antimicrobial activity against five microorganisms of Mahanintangtong formula and its constituent herbs ( $n=3)$ (Continued)

\begin{tabular}{|c|c|c|c|c|c|c|}
\hline \multirow[t]{2}{*}{ Plant name } & \multirow{2}{*}{$\begin{array}{l}\text { Extracts } \\
\text { type }\end{array}$} & \multicolumn{5}{|c|}{ Diameter of inhibition zone $(\mathrm{mm} .)^{*}, \mathrm{MIC}(\mu \mathrm{g} / \mathrm{mL})^{* *}, \mathrm{MBC}(\mu \mathrm{g} / \mathrm{mL})^{* * *}$} \\
\hline & & S. pyogenes & S. aureus & MRSA & P. aeruginosa & C. albicans \\
\hline \multirow[t]{2}{*}{ Chinese ink (Inkstick) } & Ethanol & $\mathrm{N} / \mathrm{A}$ & N/A & N/A & N/A & N/A \\
\hline & Water & $\begin{array}{l}0^{*} \\
>5^{* *} \\
>5^{* * *}\end{array}$ & $\begin{array}{l}0^{*} \\
5^{* *} \\
>5^{* * *}\end{array}$ & $\begin{array}{l}0^{*} \\
>5^{* *} \\
>5^{* * *}\end{array}$ & $\begin{array}{l}0^{*} \\
>5^{* *} \\
>5^{* * *}\end{array}$ & $\begin{array}{l}0^{*} \\
>5^{* *} \\
>5^{* * *}\end{array}$ \\
\hline \multirow[t]{2}{*}{ Monetaria moneta (Money cowry) } & Ethanol & N/A & N/A & N/A & N/A & N/A \\
\hline & Water & $\begin{array}{l}0 \\
>5^{* *} \\
>5^{* * *}\end{array}$ & $\begin{array}{l}0^{*} \\
>5^{* *} \\
>5^{* * *}\end{array}$ & $\begin{array}{l}0^{*} \\
2.5^{* *} \\
>5^{* * *}\end{array}$ & $\begin{array}{l}0^{*} \\
>5^{* *} \\
>5^{* * *}\end{array}$ & $\begin{array}{l}0 \\
>5^{* *} \\
>5^{* * *}\end{array}$ \\
\hline \multirow[t]{2}{*}{ Mahanintangtong formula } & Ethanol & $\begin{array}{l}10 \pm 0.00^{*} \\
0.078^{* *} \\
>5^{* * *}\end{array}$ & $\begin{array}{l}10 \pm 0.00^{*} \\
0.625^{* *} \\
0.625^{* *^{\prime}}\end{array}$ & $\begin{array}{l}10 \pm 0.00^{*} \\
0.625^{* *} \\
0.625^{* * *}\end{array}$ & $\begin{array}{l}0^{*}, \\
0.625^{* *} \\
0.625^{* *^{\prime *}}\end{array}$ & $\begin{array}{l}0 \\
>5^{* *} \\
>5^{* * *}\end{array}$ \\
\hline & Water & $\begin{array}{l}0 \\
>5^{* *} \\
>5^{* * *}\end{array}$ & $\begin{array}{l}0^{*} \\
0.625^{* *} \\
0.625^{* * *}\end{array}$ & $\begin{array}{l}0^{*} \\
0.625^{* *} \\
2.5^{* * *}\end{array}$ & $\begin{array}{l}0^{*}, \\
>5^{* *} \\
>5^{* *^{\prime *}}\end{array}$ & $\begin{array}{l}0 \\
>5^{* *} \\
>5^{* * *}\end{array}$ \\
\hline Amoxicillin & NT & $\begin{array}{l}35.00 \pm 0.00^{*} \\
0.016^{* *} \\
0.0256^{* * *}\end{array}$ & NT & NT & NT & NT \\
\hline Ampicillin & NT & NT & $\begin{array}{l}43.00 \pm 0.00^{*} \\
0.25^{* *} \\
1.56^{* * *}\end{array}$ & NT & NT & NT \\
\hline Gentamicin & NT & NT & $\begin{array}{l}15.00 \pm 0.00^{*} \\
0.195^{* *}, \\
0.195^{* *^{\prime *}}\end{array}$ & $\begin{array}{l}10.00 \pm 0.00^{*} \\
>200^{* *}, \\
>200^{* *^{*}}\end{array}$ & $\begin{array}{l}12.00 \pm 0.00^{*}, \\
0.195^{* * *}, \\
0.39^{* * * \prime^{\prime}}\end{array}$ & NT \\
\hline Vancomycin & NT & $\begin{array}{l}15.00 \pm 0.00^{*} \\
0.39^{* *} \\
0.39^{* *^{\prime}}\end{array}$ & $\begin{array}{l}45.00 \pm 0.00^{*} \\
0.003^{* *}, \\
1.92^{* * * *^{\prime}}\end{array}$ & $\begin{array}{l}16.00 \pm 0.00^{*} \\
0.78^{* *} \\
1.56^{* * *}\end{array}$ & NT & NT \\
\hline
\end{tabular}

Means of three measurements + SEM $(n=3)$. Amoxicillin, Ampicillin, Gentamicin and Vancomycin were tested at $10 \mu \mathrm{g} / \mathrm{disc}$. NT Not Test, N/A Not Applicab

was dose-dependent in the range of $1-100 \mu \mathrm{g} / \mathrm{mL}$ of ethanol extract. D. loureiroi had the greatest inhibitory effect with an $\mathrm{IC}_{50} 12.02 \pm 0.30 \mu \mathrm{g} / \mathrm{mL}$ (Table 3). Inhibition was less for the aqueous extracts.

\section{Cytotoxicity}

At concentrations of 50 and $100 \mu \mathrm{g} / \mathrm{mL}$ of ethanol and water extracts, there was no effect on cell viability. At all concentrations tested, there was more than $70 \%$ of cell viability.

\section{Antioxidant assay}

Several assays have been frequently used to estimate antioxidant activity of crude plant extracts. The most used assays are ABTS and DPPH because they both involve $\mathrm{H}$ - or electron-donation to the antioxidant [22]. Moreover, both have excellent stability under certain conditions. High ABTS scavenging activity was seen with the ethanol and water extracts of $D$. loureiroi and the ethanol extract of $T$. grandis as well as the water extract of S. pinnata (carbonized) and E. rheedii (carbonized). $\mathrm{IC}_{50 \mathrm{~s}}$ ranged from 8 to $10 \mu \mathrm{g} / \mathrm{mL}$ compared to the positive controls: Trolox $=4.71 \pm 0.04 \mu \mathrm{g} / \mathrm{mL}$ and $\mathrm{BHT}=$ $5.66 \pm 0.26 \mu \mathrm{g} / \mathrm{mL}$ (Table 4.). In the DPPH assay, the ethanol extract of $S$. pinnata (carbonized) showed the highest activity with $\mathrm{IC}_{50}$ of $5.72 \pm 0.90 \mu \mathrm{g} / \mathrm{mL}$ compared to $14.87 \pm 0.94$ (BHT) and $5.02 \pm 0.20$ (Trolox, Table 4).

\section{Discussion}

In this, the first study to examine the properties of Mahanintangtong, we have shown that it possesses good anti-inflammatory activity and good antimicrobial activity, especially against $S$. pyogenes, an important cause of illnesses like pharyngitis [23].

In Thai traditional medicine, symptoms and diseases are thought to be due to an imbalance of the hot and cold elements in body and the carbonized herbs of the Mahanintangtong formula are used to reduce Pitta (fire element) for illnesses like aphthous stomatitis, measles, chicken pox in children up to 12 years old [12, 24]. Research can substantiate the scientific bases for using traditional medicines and bring to light important compounds that could, with future development, be used in patients. This was the rationale of our study in which we used 6 common ingredients and 5 carbonized herbs i.e. E. rheedii, S. pinnata, S. rarak, C. caesius, and T. grandis.

The extraction methods and solvents used are important in the processing of the bioactive constituents because plants contain a complex blend of phytochemicals 
Table 3 Anti-inflammatory activity by inhibitory effects on NO, TNF-a and IL-6 production in RAW264.7 cells of the Mahanintangtong formula and its constituent herbs $(n=3)$

\begin{tabular}{|c|c|c|c|c|c|}
\hline \multirow[t]{2}{*}{ Plant name } & \multirow{2}{*}{$\begin{array}{l}\text { Extracts } \\
\text { type }\end{array}$} & \multicolumn{3}{|c|}{$\mathrm{IC}_{50} \pm \mathrm{SEM}(\mu \mathrm{g} / \mathrm{ml})$} & \multirow{2}{*}{$\begin{array}{l}\text { Cytotoxic activity } \\
\% \text { Survival (conc. } 100 \mu \mathrm{g} / \mathrm{mL} \text { ) }\end{array}$} \\
\hline & & NO & TNF-a & IL-6 & \\
\hline \multirow[t]{2}{*}{ Entada rheedii (carbonized) } & Ethanol & $>100$ & $>100$ & $>100$ & $79.74 \pm 3.45$ \\
\hline & Water & $>100$ & $>100$ & $>100$ & $73.06 \pm 2.83$ \\
\hline \multirow[t]{2}{*}{ Spondias pinnata (carbonized) } & Ethanol & $>100$ & $>100$ & $>100$ & $102.65 \pm 4.72$ \\
\hline & Water & $>100$ & $>100$ & $>100$ & $88.23 \pm 0.78$ \\
\hline \multirow[t]{2}{*}{ Sapindus rarak (carbonized) } & Ethanol & $66.78 \pm 1.38$ & $>100$ & $>100$ & $71.86 \pm 3.09$ (conc. $70 \mu \mathrm{g} / \mathrm{mL})$ \\
\hline & Water & $>100$ & $>100$ & $>100$ & $95.58 \pm 6.81$ \\
\hline \multirow[t]{2}{*}{ Calamus caesius (carbonized) } & Ethanol & $>100$ & $>100$ & $>100$ & $93.97 \pm 3.99$ \\
\hline & Water & $>100$ & $>100$ & $>100$ & $107.91 \pm 6.05$ \\
\hline \multirow[t]{2}{*}{ Tectona grandis (carbonized) } & Ethanol & $52.47 \pm 3.58$ & $21.26 \pm 0.40$ & $49.38 \pm 1.44$ & $97.57 \pm 5.36$ \\
\hline & Water & $>100$ & $>100$ & $>100$ & $97.64 \pm 1.88$ \\
\hline \multirow[t]{2}{*}{ Dracaena loureiroi } & Ethanol & $9.42 \pm 1.81$ & $55.27 \pm 5.47$ & $12.02 \pm 0.30$ & $92.49 \pm 1.39$ \\
\hline & Water & $>100$ & $>100$ & $>100$ & $98.54 \pm 0.92$ \\
\hline \multirow[t]{2}{*}{ Myristica fragrans } & Ethanol & $35.78 \pm 2.22$ & $14.03 \pm 2.12$ & $55.26 \pm 4.50$ & $96.14 \pm 1.68$ (conc. $50 \mu \mathrm{g} / \mathrm{mL})$ \\
\hline & Water & $>100$ & $>100$ & $>100$ & $97.97 \pm 0.20$ \\
\hline \multirow[t]{2}{*}{ Pogostemon cablin } & Ethanol & $>100$ & $10.68 \pm 0.02$ & $17.37 \pm 0.78$ & $95.45 \pm 2.80$ \\
\hline & Water & $>100$ & $>100$ & $>100$ & $94.86 \pm 3.43$ \\
\hline \multirow[t]{2}{*}{ Tiliacora triandra } & Ethanol & $>100$ & $82.22 \pm 3.89$ & $>100$ & $96.06 \pm 23.11$ \\
\hline & Water & $>100$ & $>100$ & $>100$ & $92.05 \pm 5.54$ \\
\hline \multirow[t]{2}{*}{ Chinese ink (Inkstick) } & Ethanol & $>100$ & N/A & $\mathrm{N} / \mathrm{A}$ & $\mathrm{N} / \mathrm{A}$ \\
\hline & Water & $>100$ & $>100$ & $>100$ & $90.15 \pm 6.62$ \\
\hline \multirow[t]{2}{*}{ Monetaria moneta (Money cowry) } & Ethanol & $>100$ & N/A & N/A & $\mathrm{N} / \mathrm{A}$ \\
\hline & Water & $>100$ & $>100$ & $>100$ & $93.98 \pm 2.09$ \\
\hline \multirow[t]{2}{*}{ Mahanintangtong formula } & Ethanol & $28.03 \pm 0.64$ & $33.09 \pm 0.22$ & $17.20 \pm 0.65$ & $88.85 \pm 0.56$ \\
\hline & Water & $>100$ & $>100$ & $>100$ & $98.56 \pm 0.74$ \\
\hline Andrographolide & & $1.797 \pm 0.41$ & $5.08 \pm 3.48$ & $9.10 \pm 0.61$ & $91.58 \pm 2.87$ \\
\hline
\end{tabular}

Means of three measurements \pm SEM $(n=3)$. \% Survival was tested at 100,70 or $50 \mu \mathrm{g} / \mathrm{mL}$ after $24 \mathrm{~h}$ incubation in RAW 264.7 cells

[25]. Decoction and 95\% EtOH maceration are standard methods and we used a modification of the Thai traditional maceration method. Extract yields depend on pharmacognosy of the different parts of the plants used. The water extracts from the leaves were double those of the ethanol extracts whereas most of the EtOH extracts from wood were higher than the water extracts. For the seeds, the water extract of carbonized $E$. rheedii and $S$. pinnata seeds was higher and lower than the alcohol extracts, respectively. However, yields of water and ethanol extracts of Mahanintangtong formula were similar.

The ethanol extracts of all herbs and Mahanintangtong had greater antibacterial activity for the gram-positive $(+)$ and gram-negative (-) bacteria compared to the water extracts, especially against $S$. pyogenes; the carbonized ethanol extracts had the highest activity. Carbonization is done because it is believed to result in better tolerability but might reduce their efficacy. Never the less, our carbonized ethanol extract retained high anti streptococcal activity. Moreover, the carbonized ethanol extracts of E. rheedii, S. pinnata, S. rarak and T. grandis had greater activity against the Gram-positive bacteria compared to $P$. aeruginosa. Similar results have been reported by Sameh et al., 2019 [26] who reported that the essential oil from $S$. pinnata was highly active against MRSA and $S$. aureus. This oil contains sesquiterpenes, $\beta$-caryophyllene, oxygenated monoterpenes and $\alpha$-terpineol are the main constituent and it is noteworthy that $\beta$-caryophyllene has been shown to have potent activity against $S$. aureus, $P$. aeruginosa with MICs of $3 \pm$ 0.4 and $7 \pm 1.2 \mu \mathrm{M}$ [27]; $\alpha$-terpineol also has anti-S. pyogenes activity [28]. By contrast, Bitchagno et al. [29] demonstrated that the ethanol extract from the fruit of T. grandis showed good activity against the Gramnegative bacteria, especially $E$. coli.

The reduced anti Gram-negative activity in our study is probably due to their hydrophilic cell wall structure which is essentially made up of LPS that is impermeable 
Table 4 Antioxidant activity of the Mahanintangtong formula and its constituent herbs $(n=3)$

\begin{tabular}{|c|c|c|c|}
\hline \multirow[t]{2}{*}{ Plant name } & \multirow{2}{*}{$\begin{array}{l}\text { Extracts } \\
\text { type }\end{array}$} & \multicolumn{2}{|l|}{$\mathrm{IC}_{50} \pm \mathrm{SEM}(\mu \mathrm{g} / \mathrm{ml})$} \\
\hline & & ABTS radical-scavenging assay & DPPH radical-scavenging assay \\
\hline \multirow[t]{2}{*}{ Entada rheedii (carbonized) } & Ethanol & $22.60 \pm 0.86$ & $21.15 \pm 3.72$ \\
\hline & Water & $10.29 \pm 1.19$ & $37.34 \pm 0.54$ \\
\hline \multirow[t]{2}{*}{ Spondias pinnata (carbonized) } & Ethanol & $14.08 \pm 2.49$ & $5.72 \pm 0.90$ \\
\hline & Water & $10.18 \pm 1.05$ & $28.64 \pm 1.25$ \\
\hline \multirow[t]{2}{*}{ Sapindus rarak (carbonized) } & Ethanol & $>100$ & $>100$ \\
\hline & Water & $94.14 \pm 6.71$ & $>100$ \\
\hline \multirow[t]{2}{*}{ Calamus caesius (carbonized) } & Ethanol & $54.05 \pm 0.75$ & $58.93 \pm 2.85$ \\
\hline & Water & $26.16 \pm 1.16$ & $>100$ \\
\hline \multirow[t]{2}{*}{ Tectona grandis (carbonized) } & Ethanol & $10.13 \pm 0.77$ & $18.59 \pm 2.65$ \\
\hline & Water & $24.81 \pm 2.20$ & $30.12 \pm 1.79$ \\
\hline \multirow[t]{2}{*}{ Dracaena loureiroi } & Ethanol & $8.38 \pm 0.95$ & $16.95 \pm 1.43$ \\
\hline & Water & $10.92 \pm 1.23$ & $19.65 \pm 0.30$ \\
\hline \multirow[t]{2}{*}{ Myristica fragrans } & Ethanol & $49.69 \pm 2.02$ & $19.76 \pm 0.98$ \\
\hline & Water & $24.21 \pm 1.13$ & $30.99 \pm 1.33$ \\
\hline \multirow[t]{2}{*}{ Pogostemon cablin } & Ethanol & $63.50 \pm 3.88$ & $17.81 \pm 1.15$ \\
\hline & Water & $35.09 \pm 0.96$ & $18.10 \pm 1.72$ \\
\hline \multirow[t]{2}{*}{ Tiliacora triandra } & Ethanol & $>100$ & $65.30 \pm 2.04$ \\
\hline & Water & $79.48 \pm 2.12$ & $21.04 \pm 2.09$ \\
\hline \multirow[t]{2}{*}{ Chinese ink (Inkstick) } & Ethanol & N/A & N/A \\
\hline & Water & $>100$ & $>100$ \\
\hline \multirow[t]{2}{*}{ Monetaria moneta (Money cowry) } & Ethanol & N/A & N/A \\
\hline & Water & $>100$ & $>100$ \\
\hline \multirow[t]{2}{*}{ Mahanintangtong formula } & Ethanol & $14.86 \pm 0.240$ & $15.31 \pm 1.01$ \\
\hline & Water & $34.43 \pm 0.47$ & $22.58 \pm 1.33$ \\
\hline $\mathrm{BHT}$ & & $5.66 \pm 0.26$ & $14.87 \pm 0.94$ \\
\hline Trolox & & $4.71 \pm 0.04$ & $5.02 \pm 0.20$ \\
\hline
\end{tabular}

Means of three measurements \pm SEM $(n=3)$; BHT and Trolox were used as a positive control for antioxidant activity

to hydrophobic oils and so prevents accumulation in their cell membranes [30]. C. albicans was resistant to all extracts and this may be related to the its ability to produce extracellular enzymes that degrade and metabolize substrates on its surface. Therefore, the presence of plant extracts are a source of food to the fungi rather than inhibiting their growth but we also used a low concentration of plant extract which may part explain poor inhibition of C. albicans [31].

The ethanol extract of Mahanintangtong formula showed good anti-inflammatory activity by inhibiting the release of NO, TNF- $\alpha$ and IL- 6 and supports its use by in Thai traditional medicine. Moreover, previous research demonstrates the anti-inflammatory effect of the roots of $P$. cablin, a key component of Mahanintangtong, by inhibiting TNF- $\alpha$, IL- $1 \beta$ and IL6 in rats with experimentally-induced palmar oedema [32]. The aerial parts of $P$. cablin also inhibited TNF- $\alpha$ in a human promonocytic cell line (U937 cell) and a human colonic adenocarcinoma cell line (HT-29 cells) [33]. A major component of patchouli oil from $P$. cablin is $\beta$-patchoulene that inhibits proinflammatory cytokines such as TNF- $\alpha$, IL-1 $\beta$, IL6, PGE2 and NO; it also suppresses malondialdehyde, a marker of oxidant stress, and myeloperoxidase, a key enzyme in the respiratory burst of neutrophils [34]. Patchoulene epoxide which isolated from patchouli oil also inhibits TNF- $\alpha$, IL-1 $\beta$, IL-6, PGE2 and NO and downregulates mRNA expression of COX-2 and inducible nitric oxide synthetase [35]. Another important component, the ethanol extract from the bark of $T$. grandis, also inhibits TNF- $\alpha$ in RAW 264.7 cells and immortalized mouse splenic dendritic cells [36]. Phytochemicals present in $T$. grandis include naphthoquinone, anthraquinone, monoterpene, diterpene, triterpene, apocarotenoid, phenolic compounds 
and flavonoids, steroids/saponins, phenylpropanoids and fatty esters [37]. Lapachol, a naphthoquinone, has anti-inflammatory properties in a rat model [38] as do the anthraquinones rubiadin [39] and obtusifolin [40]. Other research has shown that the methanol extract of $D$. loureiroi has antipyretic properties using the brewer's yeast induced fever method [41]. Taken together, these data show clearly that different key constituents of Mahanintangtong formula possess anti-inflammatory properties and support the use of Mahanintangtong formula in Thai traditional medicine.

We used the DPPH and $\mathrm{ABTS}^{+}$assays to assess antioxidant activity of our extracts. Although they share the same mechanism of antioxidant action i.e. electron transfer, DPPH radicals are more suitable for lipophilic antioxidants while ABTS+ radicals can react with both hydrophilic and lipophilic antioxidants. We demonstrated the antioxidant activities of E. rheedii, S. pinnata, $T$. grandis and D. loureiroi, consistent with previous research. Rheediinosides A and B from E. rheedii [42] and the ethanol extract of $D$. loureiroi have been shown to possess potent antioxidant activity [43] whilst $S$. pinnata decreased significantly the levels of antioxidant enzymes [44] and showed similar antioxidant activity as in our study [45].

In 1999, the list of herbal medicine in the NLEM was announced. Mahanintangtong is one of herbal formulas on the list. However, there are no scientific reports on the formula. The present study is the first one to emphasize the antimicrobial, anti-inflammatory and antioxidant activities of Mahanintangtong formula extract. We focused on in-vitro pharmacological activity against sore throat. Our findings suggest that the ethanol of Mahanintangtong formula extract could be used to decrease inflammation, and it also showed antibactericidal action, especially $S$. pyogenes. This research supports Thai traditional medicine wisdom, and it can promote the use of Mahanintangtong in hospitals and primary health care units. However, both the quality and quantity of herbal raw materials are one of the main challenges for a Thai herbal product industry. This is in contrast with Western medicine that uses chemical drugs. Thus, the variation between different production batches is limited. In our next research, we would like to study the quality control of the chemical constituents of Mahanintangtong formula. Also, the evidence-based in vivo and clinical practice should be studied so that it is possible that the Mahanintangtong will be developed in biofilm formation.

\section{Conclusion}

This study has brought to light the antimicrobial, antiinflammatory and antioxidant activities of the Mahanintangtong formula and its constituent herbs. The
Mahanintangtong ethanol extract had significant anti $S$. pyogenes activity and significant anti-inflammatory activity that was due to $D$. loureiroi. These results support the use of Mahanintangtong in Thai traditional medicine for minor febrile illnesses and additional development work for possible future clinical use outside of traditional medicine.

\begin{abstract}
Abbreviations
ABTS: 2,2'-Azino-bis (3-ethylbenzo-thiazoline-6-sulfonic acid) diammonium salt; BHT: Butylated hydroxytoluene; DMEM: Dulbecco's modified eagle medium; DMSO: Dimethylsulfoxide; DPPH: 2, 2 -Diphenyl-1-picrylhydrazyl; EtOH: Ethanol; FBS: Fetal bovine serum; HCl: Hydrochloric acid; IL-

6: Interleukin 6; LPS: Lipopolysaccharide from E. coli O55:B5; MBC: Minimum bactericidal concentration; MHA: Mueller-Hinton agar; MHB: Mueller-Hinton broth; MIC: Minimum Inhibitory Concentration; MRSA: Methicillin resistant Staphylococcus aureus; MTT: Thiazolyl blue tetrazolium bromide; NO: Nitric oxide; OD: Optical density; PBS: Phosphate buffer saline; RAW 264.7: Mouse macrophage leukemia-like; SRB: Sulphorhodamine B; TNF-a: Tumor necrosis factor a
\end{abstract}

\section{Acknowledgments}

The authors also thank the Faculty of Medicine, Thammasat University for support and provide laboratory facilities. Also, we thank Dr. Bob Taylor for reviewing the manuscript.

\section{Authors' contributions}

$\mathrm{BD}$ conceived and designed most of the experiments. PP and JC performed most of the experiments. $\mathrm{KJ}$ carried out the anti-inflammatory activity. OP performed data analysis. BD and TJ analyzed the remaining data and wrote the manuscript. All authors read and approved the manuscript.

\section{Funding}

This work was supported by Thammasat University research grants [grant numbers $2 / 38 / 2559,2016]$ for providing logistic support, and Faculty of Medicine, Thammasat University [grant numbers 2-13/2562, 2019] for providing financial support and equipment used for biological assays.

Availability of data and materials

The datasets used and/or analyzed during the current study are available from the corresponding author on reasonable request.

\section{Declarations}

Ethics approval and consent to participate Not applicable.

\section{Consent for publication}

Not applicable.

\section{Competing interests}

The authors declare that there is no conflict of interests regarding the publication of this paper.

\section{Author details}

${ }^{1}$ Department of Applied Thai Traditional Medicine, Faculty of Medicine, Thammasat University, Pathum Thani 12120, Thailand. ${ }^{2}$ Faculty of Public Health, Thammasat University, Pathum Thani 12120, Thailand.

Received: 16 July 2020 Accepted: 14 March 2021

Published online: 30 March 2021

\section{References}

1. Banerjee S, Ford C. Clinical decision rules and strategies for the diagnosis of group A streptococcal infection: a review of clinical utility and guidelines. Ottawa: Canadian Agency for Drugs and Technologies in Health; 2018. https://pubmed.ncbi.nlm.nih.gov/30329249/.

2. Kellum JA, Kong L, Fink MP, Weissfeld LA, Yealy DM, Pinsky MR, Fine J, Krichevsky A, Delude RL, Angus DC. Understanding the inflammatory 
cytokine response in pneumonia and sepsis: results of the genetic and inflammatory markers of Sepsis (GenIMS) study. Arch Intern Med. 2007; 167(15):1655-63. https://doi.org/10.1001/archinte.167.15.1655.

3. Barton GM. A calculated response: control of inflammation by the innate immune system. J Clin Invest. 2008;118(2):413-20. https://doi.org/10.1172/ JCl34431.

4. Roth J. Endogenous antipyretics. Clin Chim Acta. 2006;371(1-2):13-24. https://doi.org/10.1016/j.cca.2006.02.013.

5. Walter EJ, Hanna-Jumma S, Carraretto M, Forni L. The pathophysiological basis and consequences of fever. Crit Care. 2016;20(1):200. https://doi.org/1 0.1186/s13054-016-1375-5.

6. Sharma JN, Al-Omran A, Parvathy SS. Role of nitric oxide in inflammatory diseases. Inflammopharmacology. 2007;15(6):252-9. https://doi.org/10.1007/ s10787-007-0013-X.

7. Agence Francaise de Securite Sanitaire des Produits de Sante. Systemic antibiotic treatment in upper and lower respiratory tract infections: official French guidelines. Clin Microbiol Infect. 2003:9(12):1162-78.

8. Elmolla $\mathrm{E}_{1}$ Chaudhuri M. Optimization of Fenton process for treatment of amoxicillin, ampicillin and cloxacillin antibiotics in aqueous solution. J Hazard Mater. 2009;170(2-3):666-72. https://doi.org/10.1016/j.jhazmat.2009.05.013.

9. Walsh FM, Amyes SG. Microbiology and drug resistance mechanisms of fully resistant pathogens. Curr Opin Microbiol. 2004;7(5):439-44. https://doi.org/1 0.1016/j.mib.2004.08.007.

10. Maia MF, Moore SJ. Plant-based insect repellents: a review of their efficacy, development and testing. Malar J. 2011;10(Suppl 1):S11. https://doi.org/1 0.1186/1475-2875-10-S1-S11.

11. Luciano-Montalvo C, Boulogne I, Gavillan-Suarez J. A screening for antimicrobial activities of Caribbean herbal remedies. BMC Complement Altern Med. 2013;13(1):126. https://doi.org/10.1186/1472-6882-13-126.

12. The Committee of National List of Essential Drugs. National List of Essential Drugs 2012. Bangkok: Ministry of Public Health; 2012.

13. Dechayont B, Hansakul $P$, Itharat A. Comparison of antimicrobial, antioxidant activities and total phenolic content of Antidesma thwaitesianum fruit extracts by different methods. J Med Assoc Thai. 2012:95(Suppl 1):S147-53.

14. Lorian V. Antibiotics in laboratory medicine. 4th ed. Baltimore: Williams \& Wilkins; 1996.

15. Singh V, Bala M, Kakran M, Ramesh V. Comparative assessment of CDS, CLSI disc diffusion and Etest techniques for antimicrobial susceptibility testing of Neisseria gonorrhoeae: a 6-year study. BMJ Open. 2012;2(4):e000969. https:// doi.org/10.1136/bmjopen-2012-000969.

16. Elshikh M, Ahmed S, Funston S. Resazurin-based 96-well plate microdilution method for the determination of minimum inhibitory concentration of biosurfactants. Biotechnol Lett. 2016;38(6):1015-9. https://doi.org/10.1007/s1 0529-016-2079-2

17. Dechayont B, Phuaklee P, Chunthorng-Orn J, Poomirat S, Juckmeta T, Phumlek K, Mokmued K, Ouncharoen K. Antimicrobial, anti-inflammatory, and antioxidant activities of the wood of Myristica fragrans Houtt. Int J Geogr Inf Syst. 2020;26(1):49-60.

18. Dechayont $B$, Itharat $A$, Phuaklee $P$, Chunthorng-Orn J, Juckmeta T, Prommee N, Nuengchamnong N, Hansakul P, et al. Antioxidant activities and phytochemical constituents of Antidesma thwaitesianum Mull. Arg. Leaf extracts. J Integr Med. 2017;15(4):310-9. https://doi.org/10.1016/S2095-4964 (17)60334-0.

19. Oh YC, Jeong YH, Kim T, Cho WK, Ma JY. Anti-inflammatory effect of Artemisiae annuae herba in lipopolysaccharide-stimulated RAW 264.7 cells. Pharmacogn Mag. 2014;10(Suppl 3):S588-95. https://doi.org/10.4103/ 0973-1296.139793.

20. Suthisamphat N, Dechayont B, Phuaklee P, Prajuabjinda O, Vilaichone R-K, Itharat A, Mokmued K, Prommee N. Anti-Helicobacter pylori, AntiInflammatory, Cytotoxic, and Antioxidant Activities of Mace Extracts from Myristica fragrans. Evid Based Complement Altern Med. 2020;7576818:6.

21. Re R, Pellegrini N, Proteggente A, Pannala A, Yang M, Rice-Evans C. Antioxidant activity applying an improved ABTS radical cation decolorization assay. Free Radic Biol Med. 1999;26(9-10):1231-7. https://doi. org/10.1016/S0891-5849(98)00315-3

22. Lee BW, Lee JH, Gal SW, Moon YH, Park KH. Selective ABTS radical-scavenging activity of prenylated flavonoids from Cudrania tricuspidata. Biosci Biotechnol Biochem. 2006;70(2):427-32. https://doi.org/10.1271/bbb.70.427.

23. Bosch AA, Biesbroek G, Trzcinski K, Sanders EA, Bogaert D. Viral and bacterial interactions in the upper respiratory tract. PLoS Pathog. 2013;9(1):e1003057. https://doi.org/10.1371/journal.ppat.1003057.
24. Mukherjee PK. Evidence-based validation of herbal medicine. 1st ed. Elsevier; 2015. https://www.elsevier.com/books/evidence-based-validationof-herbal-medicine/mukherjee/978-0-12-800874-4

25. Sasidharan S, Chen Y, Saravanan D, Sundram KM, Yoga LL. Extraction, isolation and characterization of bioactive compounds from plants' extracts. Afr J Tradit Complement Altern Med. 2011:8(1):1-10.

26. Sameh S, Al-Sayed E, Labib RM, Singab ANB. Comparative metabolic profiling of essential oils from Spondias pinnata (Linn. F.) Kurz and characterization of their antibacterial activities. Ind Crop Prod. 2019;137:46874. https://doi.org/10.1016/j.indcrop.2019.05.060.

27. Dahham SS, Tabana YM, lqbal MA, Ahamed MB, Ezzat MO, Majid AS, Majid AM The anticancer, antioxidant and antimicrobial properties of the Sesquiterpene beta-Caryophyllene from the essential oil of Aquilaria crassna. Molecules. 2015; 20(7):11808-29. https://doi.org/10.3390/molecules200711808.

28. Oyedemi SO, Okoh Al, Mabinya LV, Pirochenva G, Afolayan AJ. The proposed mechanism of bactericidal action of eugenol, $\gamma$-terpineol and $\mathrm{g}$ terpinene against Listeria monocytogenes, Streptococcus pyogenes, Proteus vulgaris and Escherichia coli. Afr J Biotechnol. 2009;8(7):1280-6.

29. Bitchagno GT, Sama Fonkeng L, Kopa TK, et al. Antibacterial activity of ethanolic extract and compounds from fruits of Tectona grandis (Verbenaceae). BMC Complement Altern Med. 2015;15(1):265. https://doi. org/10.1186/s12906-015-0790-5

30. Beveridge TJ. Structures of gram-negative cell walls and their derived membrane vesicles. J Bacteriol. 1999;181(16):4725-33. https://doi.org/10.112 8/JB.181.16.4725-4733.1999.

31. Chaffin WL, Lopez-Ribot JL, Casanova M, Gozalbo D, Martinez JP. Cell wall and secreted proteins of Candida albicans: identification, function, and expression. Microbiol Mol Biol Rev. 1998;62(1):130-80. https://doi.org/10.112 8/MMBR.62.1.130-180.1998

32. Li CW, Wu XL, Zhao XN, et al. Anti-inflammatory property of the ethanol extract of the root and rhizome of Pogostemon cablin (Blanco) Benth. Sci World J. 2013:2013:434151.

33. Li YC, Xian YF, Ip SP, Su ZR, Su JY, He JJ, Xie QF, Lai XP, Lin ZX, et al. Antiinflammatory activity of patchouli alcohol isolated from Pogostemonis Herba in animal models. Fitoterapia. 2011;82(8):1295-301. https://doi.org/1 0.1016/j.fitote.2011.09.003.

34. Zhang Z, Chen X, Chen H, Wang L, Liang J, Luo D, Liu Y, Yang H, Li Y, Xie J, Su $Z$, et al. Anti-inflammatory activity of beta-patchoulene isolated from patchouli oil in mice. Eur J Pharmacol. 2016;781:229-38. https://doi.org/10.1 016/j.ejphar.2016.04.028.

35. Liang JL, Wu JZ, Liu YH, et al. Patchoulene epoxide isolated from patchouli oil suppresses acute inflammation through inhibition of NF-kappaB and Downregulation of COX-2/iNOS. Mediat Inflamm. 2017:1089028.

36. Degbe M, Debierre-Grockiego F, Tete-Benissan A, et al. Extracts of Tectona grandis and Vernonia amygdalina have anti-toxoplasma and proinflammatory properties in vitro. Parasite. 2018;25:11.

37. Vyas $P$, Yadav DK, Khandelwal P. Tectona grandis (teak) - a review on its phytochemical and therapeutic potential. Nat Prod Res. 2019;33(16):233854. https://doi.org/10.1080/14786419.2018.1440217.

38. de Almeida ER, da Silva Filho AA, dos Santos ER, Lopes CA. Antiinflammatory action of lapachol. J Ethnopharmacol. 1990;29(2):239-41. https://doi.org/10.1016/0378-8741(90)90061-W.

39. Zarezadeh A, Mousavi Z, Asgarpanah J, Najafizadeh P. Anti-inflammatory activity of rubiadin in carrageenan induced paw edema method in rat. $2^{\text {nd }}$ international congress on biomedicine. https://www.icbcongress.com/2018/ en/prp.php?o=1129\&st=Anti-inflammatory-Activity-of-Rubiadin-in-Carra geenan-Induced-Paw-Edema-Methodin-Rat.

40. He ZW, Wei W, Li SP, Ling Q, Liao KJ, Wang X. Anti-allodynic effects of obtusifolin and gluco-obtusifolin against inflammatory and neuropathic pain Biol Pharm Bull. 2014;37(10):1606-16. https://doi.org/10.1248/bpb.c14-00307.

41. Reanmongkol W, Subhadhirasakul S, Bouking P. Antinociceptive and antipyretic activities of extracts and fractions from Dracaena loureiri in experimental animals. Songklanakarin J Sci Technol. 2003;25(4):467-76.

42. Nzowa LK, Barboni L, Teponno RB, Ricciutelli M, Lupidi G, Quassinti L, Bramucci M, Tapondjou LA, et al. Rheediinosides a and B, two antiproliferative and antioxidant triterpene saponins from Entada rheedii. Phytochemistry. 2010;71(2-3):254-61. https://doi.org/10.1016/j.phytochem.2 009.10.004.

43. Makchuchit S, Itharat A, Tewtrakul S. Antioxidant and nitric oxide inhibition activities of Thai medicinal plants. J Med Assoc Thail. 2010;93(Suppl 7):S22735. 
44. Iqbal SS, Mujahid M, Kashif SM, Khalid M, Badruddeen, Arif M, Bagga P, Akhtar J, Rahman MA, et al. Protection of hepatotoxicity using Spondias pinnata by prevention of ethanol-induced oxidative stress, DNA-damage and altered biochemical markers in Wistar rats. Integr Med Res. 2016;5(4): 267-75. https://doi.org/10.1016/j.imr.2016.05.002.

45. Hazra B, Biswas S, Mandal N. Antioxidant and free radical scavenging activity of Spondias pinnata. BMC Complement Altern Med. 2008;8:63.

\section{Publisher's Note}

Springer Nature remains neutral with regard to jurisdictional claims in published maps and institutional affiliations.

Ready to submit your research? Choose BMC and benefit from:

- fast, convenient online submission

- thorough peer review by experienced researchers in your field

- rapid publication on acceptance

- support for research data, including large and complex data types

- gold Open Access which fosters wider collaboration and increased citations

- maximum visibility for your research: over $100 \mathrm{M}$ website views per year

At $\mathrm{BMC}$, research is always in progress.

Learn more biomedcentral.com/submissions 